\title{
PHENOLIC COMPOUNDS CONTENT, ANTIOXIDANT AND ANTIDIABETIC POTENTIALS OF SEVEN EDIBLE LEAVES
}

\author{
Betül Akyurt $^{1}$, Bülent Başyiğit ${ }^{2 *}$, Mustafa Çam ${ }^{1}$ \\ ${ }^{1}$ Food Engineering Department, Engineering Faculty, Erciyes University, Kayseri, Turkey \\ ${ }^{2}$ Food Engineering Department, Engineering Faculty, Harran University, Şanlıurfa, Turkey
}

Received / Geliş: 19.07.2018; Accepted / Kabul: 30.09.2018; Published online / Online bask1: 24.10.2018

Akyurt, B., Bassyiğit, B., Cam, M. (2018). Phenolic compounds content, antioxidant and antidiabetic potentials of seven edible leaves. GIDA (2018) 43 (5): 876-885 doi: 10.15237/gida.GD18076

Akyurt, B., Başyiğit, B., Çam, M. (2018). Yedi yenilebilir yaprağın fenolik bileşik içeriği, antioksidan ve antidiyabetik potansiyeli. GIDA (2018) 43 (5): 876-885 doi: 10.15237/gida.GD18076

\begin{abstract}
The objectives of this study were to investigate antioxidant and enzyme inhibitory activity of ethanolic and aqueous extracts of seven leaves. The antioxidant activity of the leaves was determined by two different methods: DPPH and $\beta$-carotene- bleaching test $(\beta C)$. The enzyme inhibitory activity was evaluated against $\alpha$-glucosidase. Antioxidant $\left(\mathrm{EC}_{50}\right)$ and $\alpha$-glucosidase $\left(\mathrm{IC}_{50}\right)$ activity were determined as $8.29-238.8 \mathrm{~g}$ of leaf $/ \mathrm{g}$ of DPPH and 35.59-620.29 $\mu \mathrm{g} / \mathrm{mL}$ respectively. Among seven leaves studied, leaf of grape (Vitis vinifera), quince (Cydonia oblonga) and nettle (Urtica dioica) exhibited higher antioxidant and $\alpha$-glucosidase inhibition activity than the rest of the leaves. Total phenolic content (TPC), total flavonoid content (TFC) and total hydrolyzable tannin content (TTC) of the leaves were between $0.22-16.37 \mathrm{mg}$ gallic acid equivalents (GAE), 0.07-9.32 mg catechin equivalents (CE) and 0.49-16.38 tannic acid equivalent (TAE) per g of leaf, respectively.
\end{abstract}

Keywords: Antioxidant activity, edible leaves, enzyme inhibitory activity, $\alpha$-glucosidase activity

\section{YEDİ YENILLEBILLIR YAPRAĞIN FENOLİK BİLEŞİ İÇERİĞİ, ANTİOKSİDAN VE ANTİDIYYABETIIK POTANSİYELİ}

\section{ÖZ}

Bu çalışmanın amacı seçilmiş yedi tane yenilebilir yaprağın etanolik ve sulu ekstrelerinin antioksidan ve enzim inhibitör aktivitelerinin belirlenmesidir. Yaprakların antioksidan kapasiteleri DPPH ve $\beta$ Karoten ağartma yöntemleri kullanılarak analiz edilmiştir. Enzim inhibitör aktivite analizinde ise yaprakların $\alpha$-glukozidaz enzimini inhibe etme özelliği tespit edilmiştir. Yaprakların antioksidan $\left(\mathrm{EC}_{50}\right)$ ve $\alpha$-glukozidaz (IC50) aktiviteleri sırasiyla 8.29-238.8 g örnek/g DPPH ve 35.59-620.29 $\mu \mathrm{g} / \mathrm{mL}$ arasında bulunmuştur. İncelenen yapraklar arasında, üzüm yaprağı (Vitis vinifera), ayva (Cydonia oblonga) yaprağ1 ve 1sırgan otunun (Urtica dioica) diğer yapraklardan daha yüksek antioksidan ve a-glukosidaz inhibisyon aktivite gösterdiği belirlenmiştir. Yaprakların toplam fenolik madde miktarı (TPC), toplam flavonoid madde miktarı (TFC) ve toplam hidrolize edilebilir tanin miktar1 (TTC) sırasiyla 0.22-16.37 mg gallik asit eşdeğeri (GAE), 0.07-9.32 mg kateşin eşdeğeri (CE) ve 0.4916.38 tannik asit eşdeğeri (TAE)/g örnek arasında olduğu tespit edilmiştir. Bu çalışma, seçilmiş yedi tane yenilebilir yaprağın biyoaktif bileşenleri ile ilgili doğrudan karşılaştırmalı veriler sunmaktadır.

Anahtar kelimeler: Antioksidan aktivite, yenilebilir yapraklar, enzim inhibitör aktivitesi, $\alpha-$ glukosidaz aktivitesi

${ }^{*}$ Corresponding author/ Yazışmalardan sorumlu yazar;

$\triangle$ bulentbasyigit@harran.edu.tr @ (+90) 4143181583 县(+90) 4143183799 


\section{INTRODUCTION}

Diabetes mellitus which is defined by metabolic disorders is seen commonly all over the world (Kitabchi et al., 2009). It is important to balance the glucose level after meal in diabetic patients. $\alpha$ glucosidase secreted from intestinal chorionic epithelium plays an important role in the conversion of carbohydrates into glucose. By inhibiting $\alpha$-glucosidase, glucose levels in the blood can be balanced. $\alpha$-glucosidase inhibitors such as acarbose, miglitol, and voglibose are used as therapeutic agents for the treatment of diabetes mellitus because they help to control blood glucose levels after food uptake in diabetic patients for long time (Kumar et al., 2011). However, these drugs can also cause some problems such as diarrhoea, abdominal cramping, and flatulence (Ma et al., 2015).

Antioxidants have been commonly used to provide protection against oxidative degradation of foods by free radicals. Free radicals are known as Reactive Oxygen Species and play an important role in human body as they cause oxidative damage to the human body, eventually leading to cancer, aging, atherosclerosis, hypertension, heart attacks and other chronic diseases (Ani et al., 2006; Basma et al., 2011; Meziti et al., 2012). Human body copes with free radicals because of its antioxidant defense system. However, the balance between antioxidant defense system and free radicals could be changed in time. Therefore, intake of antioxidants is important issue to reduce oxidative damage in human body (Meziti et al., 2012). Synthetic antioxidants such as butylated hydroxytoluene and butylated hydroxyanisole gave rise to health problems are used more than natural antioxidants in food industry (Turkoglu et al., 2007).

There is also an important relationship between diabetes mellitus and Reactive Oxygen Species as oxidation caused by Reactive Oxygen Species are a harmful factor contributing to diabetes mellitus (Ceriello and Motz, 2004). Furthermore, previous studies indicated that Reactive Oxygen Species are increased under diabetic conditions (Noh and Ha, 2011).
Numerous studies suggests that consumption of natural sources decreases the risks of metabolic disorders such as diabetes mellitus and helps to cope with free radicals. Therefore, with rising consciousness level and research opportunities led the science to deeper study on usage of natural sources for the treatment of various human diseases. Edible leaves which are one of the important natural sources have also become a prominence issue and numerous researches have been made regarding their effect on human health and food quality in recent years as they are a valuable source of different bioactive compounds including secondary metabolites and macromolecules (Ju et al., 2013; Jain et al., 2017). However, to the best of our knowledge, no studies have been conducted direct comparative data on antioxidant and $\alpha$-glucosidase inhibition activities of seven edible leaves investigated in our study.

Due to all these reasons, reliable and natural resources have gained attention all over the world in these days (Braithwaite et al., 2014; Klaus et al., 2015). In this sense, spices, plants and their parts, especially leaves are the potential reliable and natural sources of bioactive compounds (Yanishlieva et al., 2006). Therefore, we have studied some analytical properties of seven edible leaves, namely grape (Vitis vinifera), quince (Cydonia oblonga), mulberry (Morus), beans (Phaseolus vulgaris), cherry (Prunus avium), nettle (Urtica dioica), chard (Beta vulgaris vulgaris) which are important parts of Turkish cuisine in the present study. The leaves were investigated for their antioxidant, $\alpha$-glucosidase inhibition activity, total phenolic, total flavonoid and total hydrolyzable tannin contents.

\section{MATERIAL AND METHOD}

\section{Plant materials and chemicals}

Leaf of grape $(V$. vinifera $)$, quince (C. oblonga), mulberry (Morus), bean (P. vulgaris) and cherry $(P$. avium) was collected from the plants in August in Kayseri city (Turkey). Leaf of chard (B. vulgaris vulgaris) and nettle (U. dioica) was supplied from markets in January. All leaves were stored at $25^{\circ} \mathrm{C}$ until analysis. Chemicals were obtained 
either from Sigma or Merck unless otherwise stated.

\section{Optimization of solvent composition}

Simplex-Lattice design was used to determine the optimum solvent concentrations. Total phenolic content in the extracts was used as response. The ratio of ethanol to water was selected as independent variable. Experiments were conducted based on following conditions: $10 \mathrm{~g}$ of milled leaf was weighed into a vial, and $150 \mathrm{~mL}$ of ethanol-water combination was added into the vial. This mixture was kept in a shaking water bath (Heat Tech $26 \mathrm{~L}$, Thermo Scientific) at $40{ }^{\circ} \mathrm{C}$ for $30 \mathrm{~min}$ and then centrifuged (Model NF800R, Nüve, Ankara, Turkey) at $4000 \mathrm{rpm}$ for $5 \mathrm{~min}$. The resulting supernatant was collected and stored at $-18{ }^{\circ} \mathrm{C}$ until analyzed. Simplex-Lattice design points, the ratio of ethanol to water, were given in Table 1. All the leaves were subjected to extraction experiments as indicated in Table 1.

Table 1. Simplex-Lattice design points for solvent optimization

\begin{tabular}{ccc}
\hline Experiment number & Water $(\%)$ & Ethanol $(\%)$ \\
\hline 1 & 50 & 50 \\
2 & 0 & 100 \\
3 & 100 & 0 \\
4 & 100 & 0 \\
5 & 25 & 75 \\
6 & 0 & 100 \\
7 & 75 & 25 \\
8 & 50 & 50 \\
\hline
\end{tabular}

\section{Total phenolic content}

Total phenolic content (TPC) of leaves was determined using Folin-Ciocalteu (Singleton and Rossi, 1965) with some modification using gallic acid as a standard. $0.4 \mathrm{~mL}$ of diluted extract solution was mixed with $2 \mathrm{~mL}$ of Folin-Ciocalteu reagent (the reagent was pre-diluted, 10 times, with distilled water) and $1.6 \mathrm{~mL}$ of sodium carbonate $(7.5 \% \mathrm{w} / \mathrm{v})$. After $60 \mathrm{~min}$ of incubation at room temperature, absorbance was measured at $765 \mathrm{~nm}$ using UV-Vis spectrophotometer (Agilent 8453, USA) versus prepared blank.

\section{Total flavonoid content}

Total flavonoid content (TFC) was determined by the method of Zhishen et al. (1999). At time zero, $1 \mathrm{~mL}$ of extract was mixed with $4 \mathrm{~mL}$ of water and $0.3 \mathrm{~mL}$ of $5 \% \quad \mathrm{NaNO}_{2}$ into a $10 \mathrm{~mL}$ volumetric flask. After $5 \mathrm{~min}, 0.3 \mathrm{~mL}$ of $10 \%$ $\mathrm{AlCl}_{3}$ was added into the flask. At 6th min, $2 \mathrm{~mL}$ of $1 \mathrm{M} \mathrm{NaOH}$ was added to the mixture. Immediately, $2.4 \mathrm{~mL}$ of distilled water was added to the mixture in order to reach a final volume and thoroughly mixed. The absorbance of the resulting pink colored solution was read at $510 \mathrm{~nm}$ versus the prepared blank. The results were expressed as $\mathrm{mg}$ catechin equivalents per $\mathrm{g}$ of leaf.

\section{Total hydrolysable tannin content}

Total hydrolyzable tannin content (TTC) of leaves was determined by the method of Willis and Allen (1998). $1 \mathrm{~mL}$ of diluted extract solution was mixed with $5 \mathrm{~mL}$ of $2.5 \% \mathrm{KIO}_{3}$. The absorbance of the resulting red colored solution was measurement at $550 \mathrm{~nm}$ versus the prepared blank. Final results were expressed as $\mathrm{mg}$ tannic acid equivalents per $\mathrm{g}$ of leaf.

\section{Antioxidant activity}

Two different antioxidant activity methods (Betacarotene bleaching and DPPH assays) were used to determine antioxidant activities of the leaves.

DPPH assay was determined according to method of Singh et al. (2002). Briefly, $0.1 \mathrm{~mL}$ of diluted extract solution was mixed with $3.9 \mathrm{~mL}$ of a $25 \mathrm{mg} / \mathrm{L}$ methanolic solution of DPPH and this mixture was vortexed for $10 \mathrm{~s}$. After $30 \mathrm{~min}$ of incubation at room temperature, absorbance was measured at $515 \mathrm{~nm}$ using UV-Vis spectrophotometer (Agilent 8453, USA) versus 
prepared blank. Final results were expressed as $\mathrm{EC}_{50}$ value which is defined as amount of sample necessary to decrease initial DPPH concentration by $50 \%$. EC 50 was expressed as gram of leaf to gram of DPPH.

$\beta$-carotene bleaching assay $(\beta C)$ was determined according to method of Singh et al. (2002). $0.2 \mathrm{mg}$ of $\beta$-carotene, $20 \mathrm{mg}$ of linoleic acid and $200 \mathrm{mg}$ of tween- 40 were dissolved in $0.2 \mathrm{~mL}$ chloroform. After removing chloroform under nitrogen flush for $5 \mathrm{~min}, 10 \mathrm{~mL}$ demineralized water was added with vigorous stirring to form an emulsion. Four milliliter of this solution was added to each tube containing $0.2 \mathrm{~mL}$ of diluted samples. The control samples were prepared by adding $0.2 \mathrm{~mL}$ of distilled water instead of samples. Absorbance was measured at $470 \mathrm{~nm}$ using UV-Vis spectrophotometer (Agilent 8453, USA) versus prepared blank which was prepared as b-carotene emulsion but without adding b-carotene. Mixtures were incubated at $50{ }^{\circ} \mathrm{C}$ in a water bath until the control sample was bleached $(90 \mathrm{~min})$. Tubes were cooled to room temperature and absorbance was re-measured. Final results were expressed as percent inhibition in B-carotene assay. $\beta$-carotene- bleaching assay $(\beta C)$ was using the following equation:

$\beta \mathrm{C}(\%)=\left[1-\left(\frac{A_{s: 0}-A_{s: 90}}{A_{c: 0}-A_{c: 90}}\right)\right] * 100$

Where $A_{s: 0}$ is the absorbance of sample at 0th min, $A_{S: 90}$ is the absorbance of sample at 90th min, $A_{c: 0}$ is the absorbance of control at 0th min, $A_{c: 90}$ is the absorbance of control at 90 th min.

\section{$\alpha$-glucosidase inhibition activity}

Alpha glucosidase inhibition activity of leaves was determined by employing the methods given in the literature (Mcdougall et al., 2005). Briefly, 50 $\mu \mathrm{L}$ of diluted extract was mixed with $1250 \mu \mathrm{l}$ phosphate buffer (pH: 6.8) and then, $50 \mu \mathrm{L}$ of glutathione, $50 \mu \mathrm{L}$ of $\alpha$-glycosidase enzyme and $125 \mu \mathrm{L}$ of substrate were added respectively to the mixture and incubated at $37^{\circ} \mathrm{C}$ for $20 \mathrm{~min}$. The reaction was stopped by adding $2 \mathrm{~mL}$ sodium carbonate. The absorbance of the reaction mixture was measured at $400 \mathrm{~nm}$. Resulting $\alpha$ glucosidase inhibitory activities were calculated as inhibition (\%) by following equation:

\section{(Absorbance of control - Absorbance of exract) \\ Inhibition $(\%)=$ Absorbance of control

The concentration of the extract required to inhibit $50 \%$ of $\alpha$-glucosidase activity under the assay conditions was defined as the $\mathrm{IC}_{50}$ value. $\mathrm{IC}_{50}$ was expressed as microgram ratio of leaf to milliliter.

\section{Statistical analysis}

A statistical software (Design Expert 7.0.0, StatEase Inc., Minneapolis, MN) was used for designing and randomizing the experimental points in Simplex-Lattice design. Quadratic models were constructed from the experimental results for each leaves. Analysis of variance, and fitting of quadratic models, and Tukey's multiple comparison tests were performed using the SPSS 22.0 statistical package for Windows (SPSS Inc., Chicago, IL).

\section{RESULTS AND DISCUSSION}

\section{Optimization of solvent concentration}

Response surface methodology is commonly used in analyzing experimental data and the optimization of different parameters (Madamba, 1997). Simplex-Lattice design was used to determine the optimum ratio of ethanol to water for the extraction of bioactive components from the leaves. The results obtained from SimplexLattice design were presented in Table 2. The best equations (Liear or quadratic) giving the highest TPC of the leaves were constructed for each leaves. The leaves were subjected to extraction at optimum solvent concentrations, and then analyzed for the determination of bioactive properties. 
Table 2. Optimum solvent concentrations and regression equations for each leaves

\begin{tabular}{ccc}
\hline Leaves & Water-Ethanol $(\%, \%)$ & Regression equation for TPC $(\mathrm{mg} / \mathrm{g})$ \\
\hline Grape & $44-56$ & $\mathrm{TPC}=13.47 \mathrm{~A}+16.16 \mathrm{~B}+17.54 \mathrm{AB}$ \\
Quince & $78-22$ & $\mathrm{TPC}=8.46 \mathrm{~A}+4.44 \mathrm{~B}+22.89 \mathrm{AB}$ \\
Mulberry & $100-0$ & $\mathrm{TPC}=2.58 \mathrm{~A}+1.11 \mathrm{~B}$ \\
Bean & $100-0$ & $\mathrm{TPC}=1.79+0.52 \mathrm{~B}$ \\
Nettle & $75-25$ & $\mathrm{TPC}=10.04 \mathrm{~A}+0.69 \mathrm{~B}+21.08 \mathrm{AB}$ \\
Cherry & $76-24$ & $\mathrm{TPC}=3.76 \mathrm{~A}+2.60 \mathrm{~B}$ \\
Chard & $100-0$ & $\mathrm{TPC}=0.67 \mathrm{~A}+0.51 \mathrm{~B}$ \\
\hline
\end{tabular}

$\mathrm{A}$ and $\mathrm{B}$ for water and ethanol concentrations, respectively

\section{Total phenolic content}

TPC of all leaves are expressed in Table 3. The TPC of the leaves ranged from 1.17 to $16.37 \mathrm{mg}$ $\mathrm{GAE} / \mathrm{g}$. There was a significant difference $(\mathrm{P}<$ $0.05)$ between the TPC of some leaves. Among seven leaves, the highest TPC was found in grape $(V$. vinifera) leaf. On the other hand, chard $(B$. vulgaris vulgaris) showed the lowest TPC which was $\sim 14$ fold lower than grape ( $V$. vinifera) leaf. Different phenolic contents are evaluated for different and the same leaves in the literature (Kubola and Siriamornpun, 2008; Uysal et al., 2016; Lima et al., 2016). TPC of seven leaves were more than those of other leaves such as coriander leaf (ranged from 0.36 to $5.45 \mathrm{mg} \mathrm{GAE} / 100 \mathrm{~g}$ ) (Wangensteen et al., 2004). TPC of seven leaves were less than those of other leaves such as carob leaf (130 mg GAE/g) (Hsouna et al., 2011), Pimpinella affinis leaf (ranged from 31.0 to $155.5 \mathrm{mg}$ GAE/g), Parrotia persica leaf (ranged from 37.7 to $506.5 \mathrm{mg}$ GAE/g), Smilax excelsa leaf (ranged from 19.3 to $239 \mathrm{mg} \mathrm{GAE} / \mathrm{g}$ ) (Dehghan et al., 2016).

\section{Total flavonoid content}

TFC of the leaves ranged from 0.43 to $9.32 \mathrm{mg}$ $\mathrm{CE} / \mathrm{g}$. The changes in flavonoid content of some leaves were statistically significant $(\mathrm{P}<0.05)$. Grape ( $V$. vinifera) leaf had the highest flavonoid content while the lowest was in chard (B. vulgaris vulgaris) (Table 3). Quince (C. oblonga) leaf and nettle ( $U$. dioica) also had high levels of TFC compared to other leaves. As shown in Table 3, linear relations were evaluated between TFC and TPC of leaves. The TFC and TPC of grape ( $V$. vinifera), nettle (U. dioica) and quince (C. oblonga) were 9.32, 6.90, $3.27 \mathrm{mg} \mathrm{CE} / \mathrm{g}, 16.37,10.95,8.75$ mg GAE/g respectively. This trend is not a surprise because of the fact that flavonoids are one of the major phenolic compounds. However, TFC of grape ( $V$. vinifera) leaf determined in our study was lower than those reported by Uysal et al. (2016) who reported that TFC of methanol and aqueous extracts of grape ( $V$. vinifera) leaf was 19.61 and $44.92 \mathrm{mg}$ rutin equivalent/g respectively. TFC of the leaves were less than those of other leaves such as Mellilotus arvensis (57.0 mg quercetin equivalent/g) and Epilobium birsutum leaves (58.45 mg quercetin equivalent/g) (Ebrahimzadeh et al., 2008). The differences between the results might be the reference materials that were catechin in our study to express the final flavonoid concentrations.

\section{Total hydrolyzable tannin content}

TTC of leaves are given in Table 3.The TTC of leaves in our study contained from 1.17 to 16.19 $\mathrm{mg}$ TAE/g. The richest source of these compounds was found by mulberry (Morus) leaf (16.18 mg TAE/g) followed by nettle (U. dioica) (9.61 mg TAE/g), chard (B. vulgaris vulgaris) (5.69 $\mathrm{mg}$ TAE/g), quince (C. oblonga) leaf $(3.93 \mathrm{mg}$ TAE/g), cherry (P. avium) leaf (3.64 mg TAE/g), bean (P. vulgaris) leaf $(2.30 \mathrm{mg}$ TAE/g) and grape (V. vinifera) leaf (1.17 $\mathrm{mg}$ TAE/g). Previous data regarding the tannin content of leaves such as aqueous extract of pomegranate leaf $(64.40 \mathrm{mg}$ TAE/g), methanol extract of pomegranate leaf (128.02 mg TAE/g) (Elfalleh et al., 2012), aqueous extract of grape leaf $(33.27 \mathrm{mg}$ rutin equivalent/g) and methanol extract of grape leaf (36.37 mg rutin equivalent/g) (Devi and Singh, 2017) were reported. 


\section{Antioxidant activity}

The results of antioxidant activity of leaves were expressed using the term $\mathrm{EC}_{50}$ (Table 3). The lower the $\mathrm{EC}_{50}$ the higher the antioxidant activity. Statistically significant differences $(P<0.05)$ were observed among some leaves in terms of antioxidant activity. Among seven edible leaves studied, nettle (U. dioica) leaf (8.29 g of leaf/g of $\mathrm{DPPH})$, grape ( $V$. vinifera) leaf (8.34 $\mathrm{g}$ of leaf/g of $\mathrm{DPPH}$ ) and quince (C. oblonga) leaf (25.43 g of leaf/g of DPPH) exhibited the highest values of antioxidant activity while the lowest was observed in cherry (P. avium), mulberry (Morus) and bean $(P$. vulgaris) leaf $(190.40,238.80$ and $288.90 \mathrm{~g}$ of leaf/g of DPPH respectively). As seen in Table $3, \beta$ carotene bleaching method $(\beta C)$, ranking of the samples with respect to their antioxidant activity was the same as that observed in DPPH assay. The $\beta C$ of the leaves ranged from 18.96 to $78.36 \%$. The grape leaf ( $V$. vinifera) performed the best in this assay with $78.36 \%$, followed nettle (U. dioica) leaf $>$ quince (C. oblonga) leaf $>$ bean (P. vulgaris) leaf $>$ chard (B. vulgaris vulgaris). Previous studies on antioxidant activity of leaf such as red cabbage $(38.6 \mu \mathrm{g} / \mathrm{mL})$ (Hassimotto et al., 2005), white grape $(0.175 \mathrm{mg} / \mathrm{mL})$ and red grape leaf (0.213 mg/mL) (Lima et al., 2016) were also reported. Antioxidant activities of the leaves determined in our study were different than those reported by these authors. The differences are due to different parameters such as cultivars, agricultural practices. Furthermore, the extraction solvents affect strongly antioxidant activity (Jang et al., 2007). For example, Elfalleh et al. (2012) indicated that antioxidant activities of aqueous and methanol extracts of pomegranate leaf were 26.65 and $11.44 \mu \mathrm{g} / \mathrm{mL}$ respectively.

\section{$\alpha$-glucosidase inhibition activity}

Activities and properties of $\alpha$-glucosidase inhibitors is very important because $\alpha$-glucosidase can release glucose as a results of some reactions such as hydrolysis of linear and branched isomaltose oligosaccharides, resulting in postprandial hyperglycemia (Casirola et al., 2006; Zhang et al., 2011). As mentioned above, commercial $\alpha$-glucosidase inhibitors have been used to treat diabetes. However, they have side effects. Therefore, consumers have turned to alternative and reliable sources possessed biological activities for treatment of diabetes mellitus, recently. We also investigated the enzyme inhibitory activity against $\alpha$-glucosidase of edible leaves as alternative and reliable sources in this study. The $\alpha$-glucosidase inhibition activities of the leaves are shown in Table 3. Five out of seven leaves exhibited the enzyme inhibitory activity against $\alpha$-glucosidase. The antidiabetic activity of leaves as $\mathrm{IC}_{50}$ was between 35.59 and $620.29 \mu \mathrm{g} / \mathrm{mL}$. The lower $\mathrm{IC}_{50}$ has higher antidiabetic activity. Grape (V. vinifera) leaf $(35.59 \mu \mathrm{g} / \mathrm{mL})$ exhibited the highest values of $\alpha$ glucosidase inhibition activity, followed by quince (C. oblonga) leaf $(71.75 \mu \mathrm{g} / \mathrm{mL})>$ nettle (U. dioica) $(97.09 \mu \mathrm{g} / \mathrm{mL})>$ bean $(P$. vulgaris) leaf $(313.72$ $\mu \mathrm{g} / \mathrm{mL})>$ cherry (P. avium) leaf $(620.29 \mu \mathrm{g} / \mathrm{mL})$ (Table 3). These results show that plants and their parts are so important source to threat metabolic diseases including diabetes (Mukherjee et al., 2006). Five leaves, especially grape ( $V$. vinifera), quince (C. oblonga) and nettle (U. dioica) leaf are potential sources for $\alpha$-glucosidase inhibitor active compounds. Previous data regarding the antidiabetic activity of vine leaf (Sendogdu et al., 2006), guince leaf (Aslan et al., 2010), mulberry leaf (Kim et al., 2013) was reported by in vivo studies. Different studies also evaluated different plants or their leaves such as spinach (6.03 $\mu \mathrm{g} / \mathrm{mL}$ ) (Vyas, 2017) Asystasia gangetica (325 $\mu \mathrm{g} / \mathrm{mL}$ ) (Reddy et al., 2010), Parrotia persica leaf (6.9 $\mu \mathrm{g} / \mathrm{mL})$, Primula beterochroma leaf (8.1 $\mu \mathrm{g} / \mathrm{mL})$, Pyrus boissieriana leaf $(4.7 \mu \mathrm{g} / \mathrm{mL}$ ) (Dehghan, 2016) Neptuniaoleracea leaf (19.09 $\mu \mathrm{g} / \mathrm{mL}$ ) (Lee et al., 2014). The results show that the $\alpha$-glucosidase inhibition varied significantly from one leaf to another.

\section{Correlation}

Pearson's correlation coefficients between the means of each variable were computed. Statistically significant $(\mathrm{p}<0.01) \quad$ correlation coefficient were observed among several bioactive compounds obtained in our study (Table 4). As expected, the highest correlation coefficient were found between the phenolic and flavonoid contents values, for which $\mathrm{R}^{2}=0.978$. The correlation coefficient between phenolic compounds and antioxidant $\left(\mathrm{EC}_{50}\right)$ and $\alpha$ - 
glucosidase inhibition $\left(\mathrm{IC}_{50}\right)$ activity was found to be $\mathrm{R}^{2}=-0.903$ and -0.765 respectively. This means that the phenolic compounds of the leaves extracts contributed by $90.3 \%$ and $76.5 \%$ to their antioxidant and $\alpha$-glucosidase inhibition activities respectively. The positive correlations between phenolic compounds and antioxidant activities in our study are similar to that demonstrated in previous studies (Barreira et al., 2008; Zhang et al., 2010). Moreover, correlation coefficients between total phenolic content and $\beta$-carotene-bleaching activity $\left(\mathrm{R}^{2}=0,969\right)$ determined in our study is similar to that reported by Leontowicz et al. (2003) who indicated that correlation coefficients, $\mathrm{R}^{2}=0.935$. Strong correlations were also observed between antioxidant activity and flavonoid compounds $\left(\mathrm{R}^{2}=-0.849\right)$ and $\alpha$ glucosidase inhibition activity $\left(\mathrm{R}^{2}=0.82\right)$. Due to the low correlation coefficients of TTC with $\mathrm{EC}_{50}$ and $\mathrm{IC}_{50}$, we could say that TTC did not play an important role on antioxidant and $\alpha$-glucosidase inhibition activities.

Table 3. Some analytical properties of leaves

\begin{tabular}{|c|c|c|c|c|c|c|}
\hline \multirow[b]{2}{*}{ Leaves } & \multicolumn{6}{|c|}{ Analytical Properties } \\
\hline & $\begin{array}{c}\text { Total } \\
\text { Phenolic } \\
(\mathrm{mg} \\
\text { GAE/g) }\end{array}$ & $\begin{array}{c}\text { Total } \\
\text { Flavonoid } \\
\text { (mg CE/g) }\end{array}$ & $\begin{array}{l}\beta \text {-carotene } \\
\text { bleaching } \\
\text { assay }(\%)\end{array}$ & $\begin{array}{c}\text { Hydrolysable } \\
\text { tannin } \\
\text { (mg TAE/g) }\end{array}$ & $\begin{array}{c}\text { Antioxidant } \\
\text { Activity } \\
\text { (g leaf/g } \\
\text { DPPH) }\end{array}$ & $\begin{array}{c}\alpha \text {-glucosidase } \\
\text { inhibition } \\
(\mu \mathrm{g} / \mathrm{mL})\end{array}$ \\
\hline Grape & $16.37 \pm 1.08^{\mathrm{a}}$ & $9.32 \pm 0.57^{\mathrm{a}}$ & $78.36 \pm 0.33^{a}$ & $1.17 \pm 0.13^{\mathrm{e}}$ & $8.34 \pm 0.71^{\mathrm{c}}$ & $35.96 \pm 13.1^{\mathrm{c}}$ \\
\hline Quince & $8.75 \pm 0.36^{c}$ & $3.27 \pm 0.16^{c}$ & $30.72 \pm 0.70^{c}$ & $3.93 \pm 0.55^{\mathrm{d}}$ & $25.43 \pm 1.12^{\mathrm{c}}$ & $71.70 \pm 26.55^{\mathrm{c}}$ \\
\hline Mulberry & $3.12 \pm 0.53^{\mathrm{cd}}$ & $1.36 \pm 0.10^{c}$ & n.d & $16.18 \pm 0.88^{a}$ & $238.80 \pm 6.86^{\mathrm{ab}}$ & n.d \\
\hline Bean & $2.12 \pm 0.13^{\mathrm{cd}}$ & $0.89 \pm 0.04^{\mathrm{cd}}$ & $21.09 \pm 0.38^{\mathrm{d}}$ & $2.30 \pm 0.70^{\mathrm{de}}$ & $288.90 \pm 26.02^{\mathrm{a}}$ & $313.70 \pm 26.50^{\mathrm{b}}$ \\
\hline Nettle & $10.95 \pm 0.22^{b}$ & $6.90 \pm 0.03^{b}$ & $48.27 \pm 1.88^{b}$ & $9.61 \pm 0.29^{b}$ & $8.29 \pm 0.07^{c}$ & $97.10 \pm 10.05^{\mathrm{c}}$ \\
\hline Cherry & $3.59 \pm 0.19^{\mathrm{d}}$ & $1.29 \pm 0.08 \mathrm{~cd}$ & n.d & $3.64 \pm 0.24^{\mathrm{d}}$ & $190.40 \pm 9.19^{\mathrm{b}}$ & $620.30 \pm 30.52^{a}$ \\
\hline Chard & $1.17 \pm 0.13^{\mathrm{d}}$ & $0.43 \pm 0.03 \mathrm{~d}$ & $18.96 \pm 1.67^{\mathrm{d}}$ & $5.69 \pm 0.50^{c}$ & n.d & n.d \\
\hline
\end{tabular}

n.d: not determined

Values are means of duplicate analysis. Data expressed as means \pm standard deviation. Means within each column with different letters $(\mathrm{a}-\mathrm{e})$ differ significantly $(P<0.05)$.

Table 4. Correlation coefficient among the levels of analyzed parameters

\begin{tabular}{lcccccc}
\hline & TPC & TFC & $\beta C$ & TTC & $\mathrm{EC}_{50}$ & $\mathrm{IC}_{50}$ \\
\hline TPC & 1 & & & & & \\
TFC & $0.978^{\mathrm{a}}$ & 1 & & & & \\
$\beta C$ & $0.947^{\mathrm{a}}$ & $0,969^{\mathrm{a}}$ & 1 & & & \\
TTC & -0.259 & -0.195 & -0.193 & 1 & 1 & \\
EC $_{50}$ & $-0.903^{\mathrm{a}}$ & $-0.849^{\mathrm{a}}$ & -0.664 & 0.298 & $0.821^{\mathrm{a}}$ & 1 \\
$\mathrm{IC}_{50}$ & $-0.765^{\mathrm{a}}$ & $-0.726^{\mathrm{b}}$ & $-0.713^{\mathrm{b}}$ & -0.143 & \\
\hline
\end{tabular}

$\mathrm{a}, \mathrm{b}=$ correlation is significant at the 0.01 and 0.05 level respectively

$\mathrm{TPC}=$ total phenolic content; $\mathrm{TFC}=$ total flavonoid content; $\beta \mathrm{C}=\beta$ - carotene bleaching assay;

TTC $=$ Total hydrolysable tannin; $\mathrm{EC}_{50}=$ antioxidant activity; $\mathrm{IC}_{50}=\alpha$-glucosidase inhibition

\section{CONCLUSION}

From the observed results, leaves of the present study were rich sources of some components such as flavonoids, tannins and phenolics. Furthermore, we indicated that some of them not only possesses these components but also exhibited antioxidant activity and inhibitory potential against $\alpha$-glucosidase in vitro.
Therefore, they could be consumed as alternative to synthetic materials and drugs for treatment some disease because of their high biological activity. On the other hand, in vitro studies are not enough for clinical studies. Further in vivo and in vitro studies are necessary to provide better knowledge about both these leaves and other plants' leaves. 


\section{ACKNOWLEDGMENTS}

Scientific Research Project Unit Erciyes University financially supported this project (Project No: FYL-2013-4245).

\section{REFERENCES}

Ani, V., Varadaraj, M.C., Naidu, K.A. (2006). Antioxidant and antibacterial activities of polyphenolic compounds from bitter cumin (Cuminum nigrum L.). Eur Food Res Technol. 224(1): 109-115.

Aslan, M., Orhan, N., Deliorman, O.D., Ergun, F. (2010). Hypoglycemic activity and antioxidant potencial of some medicinal plants traditionally used in Turkey for diabetes. J Ethnopharmacol, 128: 384-389.

Barreira, J.C., Ferreira, I.C., Oliveira, M.B.P., Pereira, J.A. (2008). Antioxidant activities of the extracts from chestnut flower, leaf, skins and fruit. Food Chem, 107(3): 1106-1113.

Basma, A.A., Zakaria, Z., Latha, L.Y., Sasidharan, S. (2011). Antioxidant activity and phytochemical screening of the methanol extracts of Euphorbia birta L. Asian Pac J Trop Biomed, 4(5): 386-390.

Bösenberg, L.H. and Van Zyl D.G. (2008). The mechanism of action of oral antidiabetic drugs: a review of recent literature. JEMDSA, 13(3):8088.

Braithwaite, M.C., Tyagi, C., Tomar, L.K., Kumar, P., Choonara, Y.E., Pillay, V. (2014). Nutraceutical-based therapeutics and formulation strategies augmenting their efficiency to complement modern medicine: An overview. $J$ Funct Foods, 6: 82-99.

Casirola, D. M. and Ferraris, R. P. (2006). AlphaGlucosidase inhibitors prevent diet-induced increases in intestinal sugar transport in diabetic mice. Metabolism, 2006(55): 832-841.

Ceriello, A. and Motz, E. (2004). Is oxidative stress the pathogenic mechanism underlying insulin resistance, diabetes, and cardiovascular disease? The common soil hypothesis revisited. Arterioscler Thromb. Vasc. Biol, 24(5): 816-823.

Dehghan, H., Sarrafi, Y., Salehi, P. (2016). Antioxidant and antidiabetic activities of 11 herbal plants from Hyrcania region, Iran. J. Food Drug Anal, 24(1): 179-188.

Devi, S. and Singh, R. (2017). Evaluation of antioxidant and anti-hypercholesterolemic potential of Vitis vinifera leaves. J. Adv. Nutr. Hum, 6(3): 131-136.

Ebrahimzadeh, M.A., Pourmorad, F., Bekhradnia, A.R. (2008). Iron chelating activity, phenol and flavonoid content of some medicinal plants from Iran. Afr. J. Biotechnol, 7(18).

Elfalleh. W., Hannachi, H., Tlili, N., Yahia, Y., Nasri, N., Ferchichi, A. (2012). Total phenolic contents and antioxidant activities of pomegranate peel, seed, leaf and flower. J. Med. Plants Res, 6(32): 4724-4730.

Hassimotto, N.A., Genovese, M.S., Lajolo, F.M. (2005). Antioxidant activity of dietary fruits, vegetables, and commercial frozen fruit pulps. $J$. Agric. Food Chem, 53: 2928-2935.

Hsouna, A.B., Saoudi, M., Trigui, M., Jamoussi, K., Boudawara, T., Jaoua, S., El Feki A. (2011). Characterization of bioactive compounds and ameliorative effects of Ceratonia siliqua leaf extract against $\mathrm{CCl} 4$ induced hepatic oxidative damage and renal failure in rats. Food Chem. Toxicol, 49(12): 3183-3191.

Jain, A., Mohapatra, A.K., Yunus, G.Y, Tiwari, R., Parakh, A., Verma, S. (2017). Estimating concentration of fluoride in edible leaves locally grown around Raipur, Chhattisgarh. J. Public. Health Dent, 15(2): 177.

Jang, H.D., Chang, K.S., Huang, Y.S., Hsu, C.L., Lee, S.H., Su, M.S. (2007). Principal phenolic phytochemicals and antioxidant activities of three Chinese medicinal plants. Food Chem, 103(3): 749756.

Ju, Y., Zhuo, J., Liu, B., Long, C. (2013). Eating from the wild: diversity of wild edible plants used by Tibetans in Shangri-la region, Yunnan, China. J. Ethnobiol Ethnomed, 9(1): 28.

Kim, J.Y., Chung, H.I., Jung, K.O., Wee, J.H., Kwon, O. (2013). Chemical profiles and hypoglycemic activities of mulberry leaf extracts vary with ethanol concentration. Food Sci. Biotechnol, 22(5): 1-5. 
Kitabchi, A.E., Umpierrez, G.E., Miles, J.M., Fisher, J.N. (2009). Hyperglycemic crises in adult patients with diabetes. Diabetes Care, 32(7): 13351343.

Klaus, A., Kozarski, M., Vunduk, J., Todorovic, N., Jakovljevic, D., Zizak, Z., Van Griensven, L.J. (2015). Biological potential of extracts of the wild edible Basidiomycete mushroom Grifola frondosa. Food Res. Int, 2015; 67: 272-283.

Kubola, J. and Siriamornpun, S. (2008). Phenolic contents and antioxidant activities of bitter gourd (Momordica charantia L.) leaf, stem and fruit fraction extracts in vitro. Food Chem, 110(4): 881890.

Kumar, S., Narwal, S., Kumar, V., Prakash, O. (2011). A-glucosidase inhibitors from plants: A natural approach to treat diabetes. Pharmacogn Rev, 5(9): 19.

Lee, S.Y., Mediani, A., Nur Ashikin, A.H., Azliana, A.B.S., Abas, F. (2014). Antioxidant and $\alpha$-glucosidase inhibitory activities of the leaf and stem of selected traditional medicinal plants. Int. Food Res. J, 21(1).

Leontowicz, M., Gorinstein, S., Leontowicz, H., Krzeminski, R., Lojek, A., Katrich, E., Trakhtenberg, S. (2003). Apple and pear peel and pulp and their influence on plasma lipids and antioxidant potentials in rats fed cholesterolcontaining diets. J. Agric. Food Chem, 51(19): 57805785.

Lima, A., Bento, A., Baraldi, I., Malheiro, R. (2016). Selection of grapevine leaf varieties for culinary process based on phytochemical composition and antioxidant properties. Food Chem, 212: 291-295.

Ma, Y.Y., Zhao, D.G., Zhou, A.Y., Zhang, Y., Du, Z., Zhang, K. (2015). A-Glucosidase inhibition and antihyperglycemic activity of phenolics from the flowers of Edgeworthia gardneri. J. Agric. Food Chem, 63: 8162-8169.

Madamba, P.S. (1997). Optimization of the drying process: An application to the drying of garlic. Drying Technol, 5(1): 117-136.

Mcdougall, G.J., Shpiro, F., Dobson, P., Smith, P., Blake, A., Stewart, D. (2005). Different polyphenolic components of soft fruits inhibit alpha-amylase and alpha-glucosidase. J. Agric. Food Chem, 53(7): 2760-2766.

Meziti, A., Meziti, H., Boudiaf, K., Mustapha, B., Bouriche, H. (2012). Polyphenolic profile and antioxidant activities of Nigella sativa seed extracts in vitro and in vivo. World Acad. Sci. Eng. Technol, 64(6): 24-32.

Mukherjee, P. K., Maiti, K., Mukherjee, K., \& Houghton, P. J. (2006). Leads from Indian medicinal plants with hypoglycemic potentials. $J$ Ethnopharmacol, 106(1): 1-28.

Noh, H. and Ha, H. (2011). Reactive oxygen species and oxidative stress. In Diabetes and the Kidney. Karger Publishers. 170: pp. 102-112.

Reddy, N.V.L.S., Anarthe ,S.J., Raghavendra, N.M. (2010). In vitro antioxidant and antidiabetic activity of Asystasia gangetica (Chinese Violet) Linn. (Acanthaceae). J. Innov. Pharm. Biol. Sci, 1(2): 72-75.

Sendogdu, N., Aslan, M., Orhan, D.D., Ergun, F., Yesilada, E. (2006). Antidiabetic and antioxidant effects of Vitis vinifera L. leaves in streptozotocin-diabetic rats. J. Pharm. Sci. Exp. Pharmacol, 3(1): 7-18.

Singh, R.P., Murthy, K.N.C., Jayaprakasha, G.K. (2002). Studies on the antioxidant activity of pomegranate (Punica granatum) peel and seed extracts using in vitro models. J. Agric. Food Chem, 50: 81-86.

Singleton, V.L. and Rossi, J.A. (1965). Colorimetry of total phenolics with phosphomolybdic-phosphotungstic acid reagents. . Am. J. Enol. Vitic, 16(3): 144-158.

Turkoglu, A., Duru, M.E., Mercan, N. (2007). Antioxidant and antimicrobial activity of Russula delica Fr: An Edidle wild mushroom. Eurasip J. Bioinf, 2(1): 54-67.

Uysal, S., Zengin, G., Aktumsek, A., Karatas, S. (2016). Chemical and biological approaches on nine fruit tree leaves collected from the Mediterranean region of Turkey. J. Funct. Foods, 22: 518-532. 
Vyas, M. (2017). Nutritional profile of spinach and its antioxidant \& antidiabetic evaluation. Int. J. Clin. Pharm, 11(03).

Wangensteen, H., Samuelsen, A.B., Malterud, K.E. (2004). Antioxidant activity in extracts from coriander. Food Chem, 88(2): 293-297.

Willis, R.B. and Allen, P.R. (1998). Improved method for measuring hydrolysable tannins using potassium iodate. Analyst, 123: 435-439.

Yanishlieva, N.V., Marinova, E., Pokorný, J. (2006). Natural antioxidants from herbs and spices. Eur. J. Lipid Sci. Technol, 108(9): 776-793.

Zhang, L., Hogan, S., Li, J.R., Sun, S., Canning, C., Zheng, S. J. (2011) Grape skin extract inhibits mammalian intestinal a-glucosidase activitand suppresses postprandial glycemic response in streptozocin-treated mice. Food Chem, 2011(126): 466-471.

Zhang, Y., Li, X., Wang, Z. (2010). Antioxidant activities of leaf extract of Salvia miltiorrhiza Bunge and related phenolic constituents. . Food Chem. Toxicol, 48(10): 2656-2662.

Zhishen, J., Mengcheng, T., Jianming, W. (1999). The determination of flavonoid contents in mulberry and their scavenging effects on superoxide radicals. Food Chem, 64(4): 555-559. 